\title{
The temperature dependence of the conductivity peak values in the single and the double quantum well nanostructures $n$-InGaAs/GaAs after IR-illumination
}

(C) Yu.G. Arapov, S.V. Gudina, A.S. Klepikova ", V.N. Neverov, G.I. Harus, N.G. Shelushinina, M.V. Yakunin Miheev Institute of Metal Physics of Ural Branch of Russian Academy of Sciences,

620990 Yekaterinburg, Russia

๑ E-mail: klepikova@imp.uran.ru

(Получена 26 апреля 2016 г. Принята к печати 20 июня 2016 г.)

The dependences of the longitudinal and Hall resistances on a magnetic field in $n$-InGaAs/GaAs heterostructures with a single and double quantum wells after infrared illumination are measured in the range of magnetic fields $B=0-16 \mathrm{~T}$ and temperatures $T=0.05-4.2 \mathrm{~K}$.

Analysis of the experimental results was carried out on a base of two-parameter scaling hypothesis for the integer quantum Hall effect. The value of the second (irrelevant) critical exponent of the theory of two-parameter scaling was estimated.

DOI: 10.21883/FTP.2017.02.44119.8302 